\title{
IMPLEMENTASI MANAJEMEN BERBASIS SEKOLAH DALAM UPAYA PENINGKATAN MUTU PENDIDIKAN AGAMA ISLAM
}

\author{
Muhamad Riyad, Ajun Rois \\ Institut Ummul Quro Al Islami (IUQI) Bogor, Institut Agama Islam \\ Nasional (IAIN) Laa Roiba Bogor \\ m.riyad@iuqibogor.ac.id, azdalea@gmail.com
}

\begin{abstract}
This study is about the implementation of school-based management and the quality of education with a sample of 30 obtained by the results of the $r$ count value of 0.48 after consultation with the interpretation table " $r$ ", then the $r$ value of 0.48 is at intervals of 0.40-0 , 59 in the Medium category. Similarly, after consultation with the product moment table $r$ value with $N=30$ at a significance level of $95 \%=0.361$, a rtable of 0.361 was obtained, indicating rcount $>$ rtable (0.48> 0.361). This shows that the implementation of SBM has a moderate role in quality management in MTs Al Mubarok, Tangerang City.
\end{abstract}

Keywords: School-Based Management, quality of education.

\begin{abstract}
Abstrak
Penelitian ini adalah tentang implementasi manajemen berbasis sekolah dengan mutu pendidikan agama Islam dengan sampel 30 diperoleh hasil $\mathrm{r}$ hitung nilai 0,48 setelah berkonsultasi dengan tabel interpretasi "r", maka nilai r 0,48 berada pada interval 0,40-0, 59 dalam kategori Sedang. Demikian pula, setelah berkonsultasi dengan tabel momen produk nilai $\mathrm{r}$ dengan $\mathrm{N}=30$ pada tingkat signifikansi $95 \%=$ 0,361 , rtabel 0,361 diperoleh, menunjukkan rhitung $>$ rtabel $(0,48>$ 0,361). Ini menunjukkan bahwa penerapan MBS memiliki peran moderat dengan mutu pendidikan agama Islam di MTs Al Mubarok, Kota Tangerang.
\end{abstract}


Thorigotuna | Jurnal Pendidikan Islam

\section{PENDAHULUAN}

Tujuan pendidikan nasional Indonesia menurut Undang Undang Nomor 20 Tahun 2003 tentang Sistem Pendidikan Nasional dinyatakan bahwa Tujuan pendidikan nasional adalah mencerdaskan kehidupan bangsa dan mengembangkan manusia Indonesia seutuhnya, yakni manusia yang beriman, dan bertaqwa terhadap Tuhan Yang Maha Esa dan berbudi pekerti luhur, memiliki pengetahuan dan ketrampilan, kesehatan jasmani dan rohani, kepribadian yang mantap dan mandiri serta tanggung jawab kemasyarakatan dan kebangsaan (UU No. 202003 Pasal 3).

Tujuan pendidikan ini termasuk di dalamnya membentuk sumber daya manusia yang berkualitas yakni bangsa yang berperilaku taqwa kepada Allah, berilmu yang amaliah, beramal yang ilmiah. Dengan harapan bangsa ini mampu hadir dan siap dan berperan dalam persaingan global yang ketat.

Namun saat ini dunia pendidikan kita belum sepenuhnya dapat memenuhi harapan mayarakat. Fenomena itu ditandai dari rendahnya mutu lulusan, penyelesaian masalah pendidikan yang tidak tuntas, atau cenderung tambal sulam, bahkan lebih berorintasi proyek. Akibatnya, seringkali hasil pendidikan mengecewakan masyarakat. Mereka terus mempertanyakan relevansi pendidikan dengan kebutuhan masyarakat dalam dinamika kehidupan ekonomi, politik , sosial, dan budaya. Kualitas lulusan pendidikan kurang sesuai dengan kebutuhan pasar tenaga kerja dan pembangunan, baik industri, perbankan, telekomunikasi, maupun pasar tenaga kerja sektor lainnya yang cenderung menggugat eksistensi sekolah. Bahkan SDM yang disiapkan melalui pendidikan sebagai generasi penerus belum sepenuhnya memuaskan bila dilihat dari segi akhlak, moral, dan jati diri bangsa dalam kemajemukan budaya bangsa (Umaedi. 2004: 1).

Timbulnya pandangan seperti ini dipengaruhi oleh faktor kondisi realita yang dialami masing- masing kelompok masyarakat melalui jumlah lulusan yang belum banyak diserap pada lapangan pekerjaan yang tersedia. Masyarakat pada dasarnya telah menyadari pada kondisi era globalisasi sekarang ini bahwa mutu pendidikan 
Muhamad Riyad, et. al I Implementasi Manajemen Berbasis...

sudah menjadi bagian yang prioritas untuk dapat diwujudkan oleh pemerintah pusat dan daerah.

Reformasi bidang politik di Indonesia pada penghujung abad ke $20 \mathrm{M}$ telah membawa perubahan besar pada kebijakan pengembangan sektor pendidikan, yang secara umum bertumpu pada dua paradigma baru yang mandiri dan demokratis. Undang-undang Nomor 22 tahun 1999 tentang otonomi daerah telah meletakkan sektor pendidikan sebagai salah satu yang harus mandiri bersama sektorsektor pembangunan yang berbasis kedaerahan lainnya seperti kehutanan, pertanian, koperasi dan pariwisata. Kemandirian di bidang pendidikan kemudian mendorong manajemen sekolah (kepala sekolah dan guru) memiliki tanggung jawab besar dalam peningkatan kualitas proses pembelajaran untuk meningkatkan kualitas hasil belajar. Baik dan buruknya kualitas hasil belajar siswa menjadi tanggung jawab guru dan kepala sekolah, karena pemerintah daerah hanya memfasilitasi berbagai aktivitas pendidikan, baik sarana prasarana, ketenagaan, maupun berbagai program pembelajaran yang direncanakan sekolah.

Undang-Undang Nomor 20 tahun 2003 tentang sistem pendidikan Nasional, sebagai pengganti undang-undang nomor 2 tahun 1989 semakin menegaskan pelibatan masyarakat dalam pengembangan sektor pendidikan, sebagaimana ditegaskan pada pasal 9 bahwa masyarakat berhak untuk berperan serta dalam perencanaan, pelaksanaan, pengawasan dan evaluasi program pendidikan. Pasal ini merupakan kelanjutan dari pernyataan pada pasal 4 ayat 1 bahwa pendidikan di Indonesia diselenggarakan secara demokratis dan berkeadilan. Demokratisasi pendidikan merupakan implikasi dari dan sejalan dengan kebijakan mendorong pengelolaan sektor pendidikan pada daerah, yang penerapannya ditingkat sekolah, baik rencana pengembangan sarana, dan alat ketanagaan, kurikulum serta berbagai program pembinaan siswa, semua diserahkan pada sekolah untuk merancangnya serta mendiskusikannya dengan mitra horizontalnya dari komite sekolah (Syafarudin. 2002: 19).

Usaha lain yang tergolong universal seperti yang dikemukakan Rahman (2005: 2) adalah penerapan Undang-Undang 
Nomor 32 tahun 2004 tentang Pemerintahan Daerah yang menyatakan bahwa otonomi pendidikan berazaskan disentralisasi, dengan pendekatan manajemen berbasis sekolah (MBS). Pendekatan MBS dimaksudkan untuk menumbuhkan kemandirian dan kreativitas kepemimpinan kepala sekolah yang kuat dan efektif. Oleh karena itu, amanat dalam Undang-undang tersebut harus menjadi dasar dan arah dalam pengembangan sekolah masa depan.

Pemberian otonomi pendidikan yang luas pada sekolah merupakan kepedulian pemerintah terhadap gejala-gejala yang muncul di masyarakat serta upaya peningkatan mutu pendid ikan secara umum. Pemberian otonomi ini menuntut pendekatan manajemen yang lebih disesuaikan dengan kondisi sekolah. Dalam kerangka inilah, MBS tampil sebagai alternatif paradigma baru manajemen pendidikan yang ditawarkan. MBS merupakan suatu konsep yang menawarkan otonomi pada sekolah untuk menentukan kebijakan sekolah dalam rangka meningkatkan mutu, efisiensi dan pemerataan pendidikan agar dapat mengakomodasi keinginan masyarakat setempat serta menjalin kerjasama yang erat antara sekolah, masyarakat dan pemerintah.

Manajemen Berbasis Sekolah merupakan suatu penawaran bagi sekolah untuk menyediakan pendidikan yang lebih baik dan lebih memadai bagi peserta didik karena MBS memberi peluang bagi kepala sekolah, guru, dan peserta didik untuk melakukan inovasi dan improvisasi di sekolah, berkaitan dengan masalah kurikulum, pembelajaran manajerial dan lain sebagainya yang tumbuh dari aktivitas, kreativitas, dan profesionalisme yang dimiliki dalam rangka meningkatkan mutu pendidikan.

Pengelolaan sekolah di beberapa sekolah telah mengembangkan MBS sebagai penerapan kebijakan kemandirian sekolah. Namun sepertinya MBS belum dapat dilaksanakan secara maksimal oleh kepala sekolah karena persepsi pemahaman kemandirian sekolah pada tingkat guru ada perbedaan. Hal ini karena tingkat pemahaman yang berbeda dari masing- masing guru dan kepala sekolah. Karena itu diperlukan sosok kepala sekolah yang berkompeten, memiliki sifat kepemimpinan yang baik, dan 
Muhamad Riyad, et. al I Implementasi Manajemen Berbasis...

terampil dalam mengelola sekolah.

MTs Al Mubarok sebagai sebuah lembaga pendidikan dikelola dan dikembangkan di bawah naungan Kementerian Agama. Sebagai sebuah lembaga pendidikan yang di bawah naungan yayasan, maka kebijakan yang dilakukan tentu saja didasarkan pada peraturanperaturan yang dikeluarkan baik oleh yayasan maupun pemerintah, baik dalam bidang administrasi, proses pendidikan, proses pengelolaan dan lain sebagainya. Karena orientasi kurikulum sekarang mengacu pada peningkatan kualitas manajemen yang berbasis sekolah, maka penekanan pengembangan yang semula berorientasi pada kuantitas berubah menjadi kualitas, mandiri, dan disentralisasi. Namun realitasnya pihak MTs Al Mubarok belum sepenuhnya mampu melaksanakan manajemen berbasis sekolah (MBS) dengan optimal.

Hal ini karena rencana dan kebijakan sekolah mutlak di tangan kepala sekolah, sehingga guru hanya bertindak jika kepala sekolah memintanya. Dibutuhkan persepsi yang positif dari seluruh guru dan komponen sekolah tentang penerapan MBS serta penciptaan iklim yang demokratisas di sekolah. Adanya persepsi positif dari seluruh komponen sekolah ini maka sekolah dapat menyelenggarakan pendidikan secara efisien dan berkualitas sesuai dengan tujuan MBS.

Berdasarkan latar belakang tersebut di atas, maka penulis tertarik untuk mengetahui sejauh mana Implementasi Manajemen Berbasis Sekolah berpengaruh terhadap peningkatan Mutu Pendidikan Agama Islam di MTs Al Mubarok.

\section{Mutu Pendidikan Agama Islam}

Menurut Edward Sallis dalam bukunya Total Quality Management in Education, Mutu adalah sebuah hal yang berhubungan dengan gairah dan harga diri. Bagi setiap institusi, mutu adalah agenda utama dan meningkatkan mutu adalah tugas yang paling penting. Meskipun demikian, ada sebagian orang yang menganggap mutu sebagai sebuah konsep yang penuh dengan teka-teki. Mutu dianggap sebagai suatu hal yang membingungkan dan sulit di ukur. 
Mutu dalam pandangan orang terkadang bertentangan dengan mutu dalam pandangan orang lain, jadi tidak anek jika ada dua pakar yang tidak memiliki kesimpulan yang sama tentang bagaimana menciptakan institusi yang baik

Menurut Deni Koswara dan Cepi Triatna dalam buku Manajemen Pendidikan, pengertian mutu memiliki fariasi sebagaimana di definisikan oleh masing-masing orang atau pihak. Produsen (penyedia barang/jasa) atau konsumen (pengguna/pemakai barang/jasa) akan memiliki definisi yang berbeda mengenai mutu barang/jasa. Perbedaan ini mengacu pada orientasi masing-masing pihak mengenai barang/jasa yang menjadi objeknya. Satu kata yang menjadi benang merah dalam konsep mutu baik menurut konsumen atau produsen adalah kepuasan. Barang atau jasa yang dikatakan bermutu adalah yang dapat memberikan kepuasan baik bagi pelanggan maupun produsenya.

Dalam konteks pendidikan Agama Islam, Mutu Pendidikan Agama Islam laksana menanam pohon yang baik, hal ini sesuai dengan firman Allah QS Ibrohim ayat 24-26

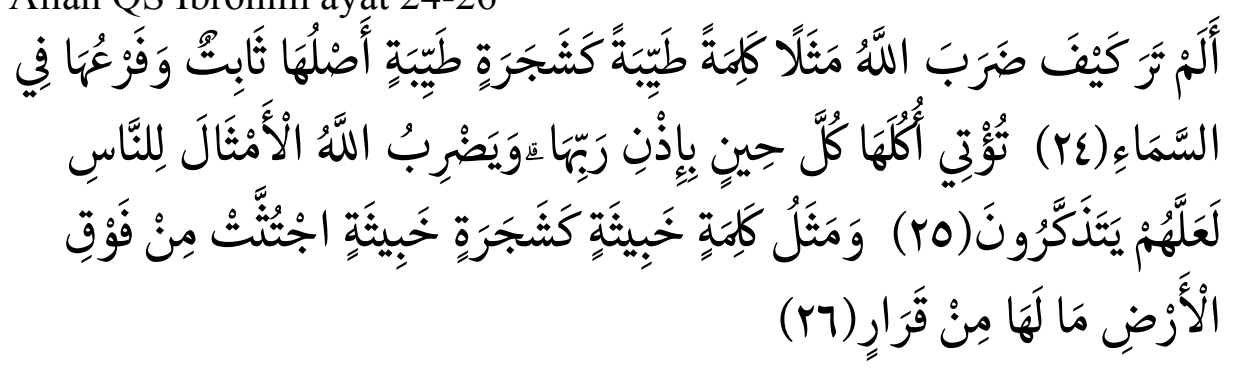

Artinya: "Tidakkah kamu perhatikan bagaimana Allah telah membuat perumpamaan kalimat yang baik seperti pohon yang baik, akarnya teguh dan cabangnya (menjulang) ke langit, (QS. 14:24) pohon itu memberikan buahnya pada setiap musim dengan seizin Rabbnya. Allah membuat perumpamaanperumpamaan itu untuk manusia supaya mereka selalu ingat. (QS. 14:25) Dan perumpamaan kalimat yang buruk seperti pohon yang buruk, yang telah dicabut dengan akar-akarnya dari permukaan bumi, tidak dapat tetap (tegak) sedikit pun. (QS. 14:26)” (QS. Ibrahim: 24-26) 
Menurut Kementrian Pendidikan Nasonal yang dikutip oleh Mulyasa, pengertian mutu mencakup input, proses, dan output pendidikan. Input pendidikan merupakan sesuatu yang harus tersedia karena dibutuhkan demi berlangsungnya suatu peroses. Sementara proses pendidikan merupakan perubahan sesuatu menjadi sesuatu yang lain. Selanjutnya, output pendidikan merupakan kinerja sekolah, yaitu prestasi sekolah yang dihasilkan dari proses dan prilaku sekolah. Oleh sebab itu, mutu dalam dunia pendidikan dapat dinyatakan lebih mengutamankan pada keberhasilan siswa. Dengan kata lain, program perbaikan sekolah dilakukan lebih secara kreatif dan konstruktif.

Penulis mendefinisikan kualitas mutu berdasarkan sudut pandangnya masing-masing. Walaupun definisi tersebut tidak diterima secara universal, tetapi terdapat beberapa kesamaan, yaitu kualitas meliputi usaha memenuhi atau melebihi harapan pelanggan dan kualitas mencakup produk, jasa, manusia, proses, dan lingkungan serta kualitas merupakan kondisi yang selalu berubah.

\section{Manajemen Berbasis Sekolah (MBS)}

Manajemen Berbasis Sekolah (MBS) pada hakikatnya adalah penyerasian sumber daya yang dilakukan secara mandiri oleh sekolah dengan melibatkan semua pemangku kepentingan yang terkait dengan sekolah secara langsung dalam proses pengambilan keputusan untuk memenuhi kebutuhan peningkatan mutu sekolah atau untuk mencapai tujuan pendidikan nasional (Riyad, 2018: 56).

Istilah manajemen berbasis sekolah merupakan terjemahan dari "school-based management". MBS merupakan paradigma baru pendidikan, yang memberikan otonomi luas pada tingkat sekolah (pelibatan masyarakat) dalam kerangka kebijakan pendidikan nasional. Menurut Edmond yang dikutip Suryosubroto merupakan alternatif baru dalam pengelolaan pendidikan yang lebih menekankan kepada kemandirian dan kreatifitas sekolah. Nurcholis mengatakan Manajemen berbasis sekolah (MBS) adalah bentuk alternatif sekolah sebagai hasil dari desentralisasi pendidikan. 
Secara umum, manajemen peningkatan mutu berbasis sekolah (MPMBS) dapat diartikan sebagai model manajemen yang memberikan otonomi lebih besar kepada sekolah dan mendorong pengambilan keputusan partisipatif yang melibatkan secara langsung semua warga sekolah (guru, siswa, kepala sekolah, karyawan, orang tua siswa, dan masyarakat) untuk meningkatkan mutu sekolah berdasarkan kebijakan pendidikan nasional.

Manajemen Berbasis Sekolah atau MBS tertuang dalam pasal 51 Undang - Undang Sistem Pendidikan Nasional yang berbunyi; pengelolaan satuan pendidikan anak usia dini, pendidikan dasar, dan pendidikan menengah dilaksanakan berdasarkan standar pelayanan minimal dengan prinsip manajemen berbasis sekolah/madrasah. Pengelolaan satuan pendidikan tinggi dilaksanakan berdasarkan prinsip otonomi, akuntabilitas, jaminan mutu, dan evaluasi yang transparan.

Definisi MBS banyak dikemukakan oleh ahli manajemen pendidikan yang berbeda antara satu dengan yang lain, namun maknanya menunjukkan adanya kesamaan persepsi tentang perlunya reformulasi manajemen secara totalitas di sekolah. Perbedaan formulasi rumusan definisi ini dilatarbelekangi pula oleh kondisi dan suasana politis serta kondisi pendidikan di beberapa negara. Berikut dikemukakan pengertian Manajemen Berbasis Sekolah dari beberapa ahli.

1. Myers dan Stonehill (1993) mengartikan MBS sebagai strategi untuk memperbaiki pendidikan dengan mentransfer otoritas pengambilan keputusan secara signifikan dari pemerintah pusat dan daerah ke sekolah-sekolah secara individual. MBS memberi kepala sekolah, guru, peserta didik, orang tua, dan masyarakat untuk memiliki kontrol yang lebih besar dalam proses pendidikan dan memberikan mereka tanggungjawab untuk mengambil keputusan tentang anggaran, personel, dan kurikulum.

2. MBS adalah suatu bentuk administrasi pendidikan, di mana sekolah menjadi unit utama dalam pengambilan keputusan. Hal ini berbeda dengan bentuk tradisional manajemen pendidikan, di 
Muhamad Riyad, et. al | Implementasi Manajemen Berbasis...

mana birokrasi pemerintah pusat sangat dominan dalam proses pembuatan keputusan.

3. MBS diartikan suatu strategi untuk memperbaiki pendidikan dengan memindahkan kewenangan pengambilan keputusan yang penting dari pemerintah pusat dan pemerintah daerah kepada pihak pengelola sekolah.

4. Manajemen Berbasis Sekolah (MBS) adalah pemberian otonomi dan kewenangan pada tingkat sekolah. Tanggung jawab dan pengambilan keputusan kegiatan operasional sekolah diserahkan kepada kepala sekolah, para guru, orang tua, para siswa, dan anggota masyarakat lainnya. Pelaksana tingkat sekolah, bagaimanapun mereka dapat menyusuaikan, atau menjalankan kegiatan sekolah sesuai kebijakan pemerintah pusat (Bank Dunia).

Lebih lanjut istilah manajemen sekolah acapkali disandingkan dengan istilah administrasi sekolah. Berkaitan dengan itu, terdapat tiga pandangan berbeda; pertama, mengartikan administrasi lebih luas dari pada manajemen (manajemen merupakan inti dari administrasi); kedua, melihat manajemen lebih luas dari pada administrasi (administrasi merupakan inti dari manajemen); dan ketiga yang menganggap bahwa manajemen identik dengan administrasi.

Dalam hal ini, istilah manajemen diartikan sama dengan istilah administrasi atau pengelolaan, yaitu segala usaha bersama untuk mendayagunakan sumber-sumber, baik personal maupun material, secara efektif dan efisien guna menunjang tercapainya tujuan pendidikan di sekolah secara optimal. Pengertian manajemen menurut Hasibuan merupakan ilmu dan seni mengatur proses pemanfaatan sumber daya manusia dan sumber-sumber lainnya secara efektif dan efisien untuk mencapai tujuan tertentu. Definisi manajemen tersebut menjelaskan pada kita bahwa untuk mencapai tujuan tertentu, maka kita tidak bergerak sendiri, tetapi membutuhkan orang lain untuk bekerja sama dengan baik.

Berdasarkan fungsi pokoknya, istilah manajemen dan administrasi mempunyai fungsi yang sama, yaitu: merencanakan (planning), mengorganisasikan (organizing), mengarahkan (directing), 
mengkoordinasikan (coordinating), mengawasi (controlling), dan mengevaluasi (evaluation).

\section{METODE}

Penelitian ini menggunakan metode Kuantitatif. Pola ini ini dimaksud untuk menganalisis pola hubungan antar variabel dengan tujuan untuk mengetahui Hubungan langsung maupun tidak langsung seperangkat vareabel bebas (eksogen) terhadap variabel terikat (endogen). Populasi terjangkau dalam penelitian ini adalah seluruh guru pada Madrasah Tsanawiyah (MTs) di Al Mubarok dengan jumlah Guru 27 dan Kepala Madrasah 1 orang beserta wakil kepala madrasah berjulah 2 orang, jadi total populasi dalam penelitian ini berjumlah 30 orang. Jumlah populasi yang kurang dari 100 maka penulis menjadikan 30 orang tersebut sebagai sampel dalam penelitian ini.

\section{HASIL DAN PEMBAHASAN}

\section{Hubungan Implementasi Manajemen Berbasis Sekolah dengan Mutu Pendidikan}

Berdasarkan hasil perhitungan yang telah dilakukan, maka dapat ditarik suatu kesimpulan bahwa implementasi Manajemen Berbasis Sekolah (MBS) memiliki hubungan yang sedang dengan Manajemen Mutu Pendidikan Agama Islam di MTs Al Mubarok, sebagai berikut:

a. Nilai $\mathrm{r}_{\text {hitung }}$ sebesar $\mathbf{0 , 4 8}$ setelah dikonsultasikan dengan tabel interpretasi nilai " $\mathrm{r}$ ", maka nilai $\mathrm{r}$ hitung sebesar 0,48 berada pada interval 0,40-0,59 dengan kategori Sedang. Demikian pula setelah dikonsultasikan dengan nilai $\mathrm{r}$ tabel product moment dengan $\mathrm{N}=30$ pada taraf signifikansi $95 \%=0,361$, diperoleh $\mathrm{r}_{\text {tabel }}$ sebesar 0,361, menunjukkan $\mathrm{r}_{\text {hitung }}>\mathrm{r}_{\text {tabel }}$ $(0,48>0,361)$. Hal ini menunjukkan bahwa implementasi MBS berperan sedang terhadap Manajemen Mutu di MTs Al Mubarok Kota Tangerang.

b. Nilai $t_{\text {hitung }}$ sebesar 2,90 dan jika dikonsultasikan dengan harga $t_{\text {tabel }}$ uji dua arah pada taraf signifikansi 0,05 dengan derajat 
kebebasan (dk) n-2 adalah 30(30-2=28), maka diperoleh $\mathrm{t}_{\text {tabel }}$ sebesar 2,048 sehingga $t_{\text {hitung }}$ sebesar 2,90 lebih besar daripada $t_{\text {tabel }}$ sebesar 2,048 atau $t_{\text {hitung }}>t_{\text {tabel }}(2,90>2,048)$. Hal ini berarti nilai $\mathrm{t}_{\text {hitung }}$ berada pada wilayah penolakan hipotesis nol. Dengan demikian maka penelitian ini menolak Hipotesis uji atau Hipotesis nol $\left(\mathrm{H}_{0}\right)$, yang berbunyi: "Tidak terdapat hubungan implementasi MBS dengan Mutu Pendidikan Agama Islam di MTs Al Mubarok Kota Tangerang" dan menerima hipotesis alternatif $\left(\mathrm{H}_{1}\right)$, yang berbunyi: "Terdapat hubungan implementasi MBS dengan Mutu Pendidikan di MTs Al Mubarok Kota Tangerang”.

c. Harga koefisien determinasi (KD) sebesar 23\%. Berarti besarnya hubungannya implementasi MBS dengan Mutu Pendidikan Agama Islam di MTs Al Mubarok Kota Tangerang sebesar23\%, atau dengan kata lain peranan MBS memberikan kontribusi sebesar 23\% terhadap Mutu Pendidikan di MTs Al Mubarok, sedangkan sisanya sebesar (100 - 23) 77\% merupakan kontribusi dari faktor-faktor lain.

\section{PENUTUP}

Kesimpulan: Implementasi Manajemen Berbasis Sekolah memiliki hubungan langsung dengan mutu Pendidikan Agama Islam. Artinya semakin tinggi implementasi manajemen berbasis sekolah mengakibatkan peningkatan mutu Pendidikan Agama Islam di MTs Al Mubarok Kota Tangerang.

Saran: Kepala sekolah atau yayasan perlu memperhatikan iplementasi manajemen berbasis sekolah di sekolah binaanya, karena dengan implementasi manajemen berbasis sekolah yang tepat akan tercapai mutu pendidikan agama Islam yang berkualitas.

\section{DAFTAR PUSTAKA}

Arikunto, Suharsimi. 2006. Prosedur Penelitian: Suatu

Pendekatan Praktek, Jakarta: Rineka Cipta, Cet ke-12.

Budiyono. 2000. Satistika Dasar Untuk Penelitian, Universitas Sebelas 
Maret. Surakarta.

Depdiknas. 2001. MPMBS, Konsep \& Pelaksanaan, Jakarta: Dirjen Dikdasmen

Djauzak, Ahmad. 1996. Penunjuk Peningkatan Mutu Pendidikan di sekolah Dasar, Jakarta: Depdikbud

Fatah, Nanang. 2003. Konsep Management Berbasis Sekolah dan Dewan Sekolah, Bandung: Pustaka Bani Quraisy

Ismail, Feiby. 2008. Manajemen Berbasis Sekolah: Solusi Peningkatan Kualitas Pendidikan. Jurnal Igra'1. Volume 5 Januari - Juni 2008

Irawan, Ade Dkk. 2004. Mendagangkan Sekolah (Studi Kebijakan Manajemen Berbasis Sekolah di DKI Jakarta), Jakarta: ICW

Mulyasa, Enco. 2004. Manajemen Berbasis Sekolah, Bandung: Remaja Rosda Karya.

Nurhasan. 2003. Konvensi Nasional Pendidikan Indonesia, Kurikulum Untuk Abad 21, Indikator Cara Pengukurandan Faktor-Faktor Yang Mempengaruhi Mutu Pendidikan, Jakarta PT. S indo

Nurkholis. 2004. Manajemen Berbasis Sekolah, Teori dan Praktek, Bandung: Remaja Rosda Karya.

Riyad, Muhamad (2018). Manajemen Pendidikan. Bogor: Langit Arbitter.

Slameto. 2005. Belajar dan Faktor-faktor yang Mempengaruhinya. Jakarta: Rineka Cipta

Sujanto, Bedjo. 2004. Mensiasati Manajemen Berbasis Sekolah Di Era Krisis Yang Berkepanjangan, Jakarta: ICW.

Suryabrata, Sumadi. 2003. Metode Penelitian. Jakarta: Rajawali

Syafarudin. 2002. Manajemen Mutu Terpadu dalam

Pendidikan. Jakarta: Grasindo

Sallis, Edward. Total Quality Management in Education. (IRCiSoD; Yogyakarta, 2015). 23.

Umaedi. 2004. Manajemen Mutu Berbasis Sekolah/Madrasah (MMBS/ M) CEQM. Jakarta: Penebar Swadaya

Walgito, Bimo. 2003. Pengantar Ilmu Psikologi. Yogyakarta: Andi Offset 